\title{
MTV to the Rescue: Changing Library Attitudes through Video
}

\section{Eileen Wakiji and Joy Thomas}

Freshmen from small environments often are intimidated by a large campus and a large library. Knowledge about and respect for libraries and confidence in librarians are considered essential to overcoming student reluctance to make effective use of either. Students at a large public university were surveyed about library use and attitudes; 78 percent of the respondents were freshmen. Of the 1,879 respondents, 61.8 percent watched an eight-minute video, which was found to influence positively their self-projected future use of libraries as well as their attitudes about libraries and librarians. Comparisons also were drawn to faculty attitudes on the same campus.

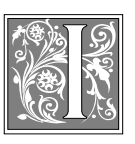

magine this scene: Two freshmen enter their university library for the first time with an assignment to write a five-page paper with at least ten references. Clueless as to how to begin and awed by the size of the library compared to their high school library, they wander in frustration until they chance upon someone about their age shelving books. They stop to ask for help, and the student assistant suggests they use. ...

From interactions at the reference desk and during library instruction, California State University, Long Beach (CSULB) librarians concluded that entering students have less understanding of basic library skills than did students in years past. This observation was supported by a report in the Los Angeles Times that about half of entering California State University (CSU) freshmen require reme- dial classes in math and English, and "the four campuses in the Los Angeles area ha[ve] the largest percentage of unprepared college freshmen." ${ }^{1}$ Also, though CSULB is by no means the largest university in the Los Angeles metropolitan area, many entering freshmen come from smaller environments and express intimidation at the sheer size of the campus (more than 26,000 students), let alone the six-story library with its million-plus volumes.

This uneasiness with library skills could be attributed, at least partially, to the fact that the number of libraries and librarians in California elementary and high schools has dropped steadily as a result of the passage of Proposition 13 in 1978: California now ranks fiftieth among the states in expenditures and staffing for public school libraries. ${ }^{2}$ Increasing numbers of public schools have 
no library and even those that have a library often have no librarian. Until very recently, many California public libraries, staggering under terrible financial deficits, were reducing hours or closing doors altogether. ${ }^{3}$ Therefore, the university's new students have had less chance to use libraries than did their predecessors and a greater likelihood of encountering libraries with inadequate re-

\section{The number of libraries and librarians in California elementary and high schools has dropped steadily as a result of the passage of Proposition 13 in 1978.}

sources. Something was needed to help acclimatize incoming students to academic libraries and librarians.

\section{Background}

In 1993 the University Library was awarded a $\$ 10,000$ grant from CSULB's Departmental Incentive Award Program to enhance library instruction. The first step of this enhancement was to produce a freshman orientation video to replace the one made in 1981. The older video, twenty-eight minutes long, had won an award from the New York Film Institute, but of course after fifteen years, it no longer presented the state-of-the-art library, nor was it produced in a manner that could be expected to capture the attention of Generation X.

Student knowledge about and respect for libraries and confidence in librarians were considered essential to overcoming their reluctance to make effective use of either. Therefore, the purpose of the new video was to encourage a positive view of libraries and to increase student comfort with doing research. Videos are an effective means of improving student attitudes toward the library, ${ }^{4}$ as opposed to such traditional methods as self-paced workbooks which, a 1991 study demonstrated, do little to improve student atti- tudes toward libraries and librarians. ${ }^{5} \mathrm{~A}$ team of CSULB librarians worked with a professional scriptwriter and the university's media production staff to create an eight-minute video entitled Liberspace, ${ }^{6}$ which was completed in 1994. The team followed the advice of an author who recommends that videos "concentrate primarily on students, ... demonstrate practice or use of library resources, ... portray an atmosphere that is comfortable, ... [and] portray reward." ${ }^{7}$

Liberspace could be described as a library infomercial or library MTV video. It is succinct and employs a rapid succession of images, punctuated by equally fast-paced music. Rather than instructing on the specifics of library use, the goal in creating Liberspace was to motivate, stimulate, and empower students, making them aware of the array of available resources and building confidence in their ability to find the information they need. Seeking guidance from a librarian is stressed.

\section{Methodology}

CSULB requires a one-unit course of all undergraduate students who enter the university with fewer than fifty-six semester units. This course, University 100 (U100), is divided into three parts: (1) the history, mission, and structure of higher education; (2) career choices and planning; and (3) library skills. Whereas the first two components are presented in a classroom setting, the lack of a sufficient number of librarians to handle the average 2,000-plus U100 students each semester has dictated that the library module be self-instructed. ${ }^{8}$ Students are expected to read the Library Skills workbook and to complete written assignments that do not require them to have much contact with librarians.

To study the effectiveness of Liberspace, the authors used primarily U100 students because of their inexperience with the CSULB campus and library. These stu- 


\begin{tabular}{|lcc|}
\hline \multicolumn{3}{|c|}{ TABLE 1 } \\
Confidence of Library & Ability \\
\hline \hline & & Graduate \\
& Undergrad. & Students \\
\hline Very confident & $6.0 \%$ & $10.3 \%$ \\
Fairly confident & 60.4 & 67.4 \\
Not very confident & 30.6 & 21.1 \\
Totally lack confidence & 2.5 & 0.5 \\
\hline Totals & $99.5 \%$ & $99.3 \%$ \\
\hline
\end{tabular}

dents for the fall 1995 semester were divided into three groups. One group viewed the video in class and immediately completed a ten-question survey; a smaller group took Liberspace home and returned the survey the next day; and a control group did not view the video but completed a shorter version of the survey. In addition to the U100 students (who were the majority of the 1,879 respondents), two other groups were included: 239 transfer students undergoing orientation, who did not watch Liberspace; and 175 social work graduate students, who did. The social work students were members of one class whose professor, a long-time library supporter, had viewed and praised the video. All CSULB social work students must write a thesis, so they were expected to be relatively sophisticated about library use.

Our contact with the student subjects was too short to do both pre- and posttests, so the authors decided to contrast the attitudes of those who viewed the video with the attitudes of those who did not. Of the 1,879 respondents, 61.8 percent $(n=1,162)$ watched the video and 38.2 percent $(\mathrm{n}=$ 717) did not.

Previous studies have shown that entering freshmen find libraries (and perhaps librarians) intimidating. ${ }^{9}$ The authors assumed that their study would replicate this finding and also that transfer and graduate students would be more comfortable with libraries and would show more confidence in their library skills. The authors expected that seeing the video would alleviate intimidation and promote better student attitudes/ opinions about libraries and librarians. A positive answer to this question would determine whether Liberspace would be used in the future. It also would provide some ammunition to help persuade those U100 faculty who were resistant to giving up the old video.

\section{Results}

The authors found that the initial attitudes about libraries and librarians of those who watched Liberspace did not differ greatly from those who did not watch it, but viewers indicated that their future behavior would change as a result of the experience. The students in the study were a surprisingly self-confident group; only 8.2 percent of undergraduates and 6.3 percent of graduate students indicated that they were frightened or intimidated by libraries. Approximately two-thirds of respondents were "very" or "fairly" confident of their ability to use a library for college work, a perception that contradicts

\section{TABLE 2}

Self-Predicted Behavior after Video, by Class Standing (Percent Answering "True")

\begin{tabular}{lll}
\hline \hline & & \\
& Undergrad. & $\begin{array}{c}\text { Graduate } \\
\text { Students }\end{array}$ \\
\hline After watching the video: & & \\
I'll be more likely to use library & $84.3 \%$ & $33.7 \%$ \\
I'll use the library more often & 80.3 & 30.3 \\
I'll be sure to talk to a librarian & 83.7 & 63.4 \\
I know more about what's available & 82.5 & 60.6 \\
I'm less intimidated by libraries & 63.1 & 27.4 \\
Library will be a greater part of college life & 85.9 & 27.4 \\
\hline
\end{tabular}




\begin{tabular}{|c|c|c|c|}
\hline \multicolumn{4}{|c|}{$\begin{array}{c}\text { TABLE } 3 \\
\text { Student Opinions about Libraries, } \\
\text { by Class Standing }\end{array}$} \\
\hline & $\begin{array}{c}\text { New } \\
\text { Students }\end{array}$ & $\begin{array}{l}\text { Transfer } \\
\text { Students }\end{array}$ & $\begin{array}{l}\text { Graduate } \\
\text { Students }\end{array}$ \\
\hline \multicolumn{4}{|l|}{ Libraries: } \\
\hline Excite me & $17.6 \%$ & $39.7 \%$ & $23.4 \%$ \\
\hline Bore me & 7.9 & 1.7 & 3.4 \\
\hline Unappealing necessity & y 24.4 & 14.6 & 29.7 \\
\hline Scare or intimidate m & e 8.4 & 7.5 & 6.3 \\
\hline No impact on me & 21.5 & 13.0 & 10.9 \\
\hline Other & 19.5 & 22.2 & 23.4 \\
\hline Totals & $99.3 \%$ & $98.7 \%$ & $97.1 \%$ \\
\hline
\end{tabular}

brarians intimidating or frightening and a mere 0.9 percent $(n=16)$ volunteered negative written comments, most respondents did not seem to grasp the role of librarians in the research process until they viewed Liberspace, when an impressive 80.4 percent of all respondents indicated that they would be sure to consult a librarian in the future. This demonstrates the effectiveness of Liberspace's message that consulting a librar-

the librarian's experience at the reference desk (see tables 1 and 3).

There was no correlation between the manner in which students had learned library use (or, indeed, if they had learned library use) and their confidence in their ability to use libraries for college-level work.

Although Edwards at Ohio State University found that "only one-half of the students felt more comfortable asking a librarian for help after completing the workbook," ${ }^{10}$ the authors' study indicates that watching a short video persuaded a high percentage of students that they would be more likely to consult a librarian in the future and to look to the library to support their research needs. Not surprisingly, the influence of Liberspace was much stronger on undergraduate students (see table 2). One could argue that graduate students are already using the library as much as necessary, hence their lower positive response to the video, although it is remarkable that a brief video could teach even presumably library-savvy graduate students not only something about library resources but also that it would be a good idea to consult a librarian when doing research.

Although only a small minority of students $(3.8 \%)$ find li- ian is beneficial.

New, transfer, and graduate students showed differing attitudes toward libraries and librarians, but not in the linear fashion expected; that is, library enthusiasm was very low among new students, peaked with transfer students, and dropped again among graduate students (see table 3).

Given their precollege experience with libraries, it is not surprising that 21.5 percent of new students believe libraries have no impact on them; but the experienced students are less likely to feel that way. Although the authors were pleased to find that only small percentages of students expressed the expected intimidation by libraries, close to a quarter of respondents found libraries "unappealing." This sad reality, coupled with the freshman belief that libraries have no

\begin{tabular}{|c|c|c|c|}
\hline \multicolumn{4}{|c|}{$\begin{array}{c}\text { TABLE } 4 \\
\text { Frequency of Library Use }\end{array}$} \\
\hline \multicolumn{2}{|c|}{ Professors } & Undergrad. & $\begin{array}{l}\text { Graduate } \\
\text { Students }\end{array}$ \\
\hline Daily & $\mathrm{n} / \mathrm{a} *$ & $8.0 \%$ & $0.0 \%$ \\
\hline Weekly or more often & n 38.2 & 38.6 & 50.9 \\
\hline Monthly & 42.4 & 29.8 & 36.6 \\
\hline Rarely & 18.7 & 20.8 & 9.7 \\
\hline Totals & $99.3 \%$ & $97.2 \%$ & $97.2 \%$ \\
\hline *Question not asked of th & this group & & \\
\hline
\end{tabular}




\begin{tabular}{|lcccc|}
\hline \multicolumn{5}{|c|}{ TABLE 5 } \\
Library Use by Gender \\
\hline & Male & Female & Male & Female \\
& Students & Students & Faculty & Faculty \\
\hline Daily & $9.3 \%$ & $6.3 \%$ & $\mathrm{n} / \mathrm{a}^{*}$ & $\mathrm{n} / \mathrm{a}^{*}$ \\
Weekly or more often & 42.2 & 38.6 & 42.0 & 31.4 \\
Monthly & 24.1 & 33.8 & 39.8 & 47.0 \\
Semester/Rarely & 20.8 & 18.9 & 18.2 & 19.9 \\
\hline Totals & $96.4 \%$ & $97.6 \%$ & $100.0 \%$ & $98.3 \%$ \\
*Question not asked of this group. & & & \\
\hline
\end{tabular}

braries than were males (see table 5).

Faculty were fairly accurate in describing how students learn library use, except in the category of "librarian consultation," where faculty thought that students use this means of library instruction much more than the students themselves reported (see table 6). Faculty slightly

impact on them, suggests the need to explore new approaches to library instruction.

It was interesting to compare what students said about their library habits with the habits of their professors and with what professors believe about students. A 1990 survey of CSULB faculty contrasted with the present one showed that students use the library with greater frequency than do professors ${ }^{11}$ (see tables 4 and 5).

The gender breakdown of respondents varied from that of the campus as a whole. During the fall 1995 semester, women represented 55.3 percent of CSULB students and 65.2 percent of respondents; men represented 44.7 percent of all students but only 34.3 percent of respondents. It is unlikely that this dissimilarity influenced survey results. Although male and female students show-ed very little difference in attitude toward librarians, their opinions about libraries and their frequency of library use diverged. Female students reported less frequent use of the library than male students, but were both more positive about and more fearful of li- overvalued the place of "course or part of a course" and greatly undervalued their own influence in teaching library use. In 1990 "nearly a quarter of the [CSULB professor] respondents expressed what might be called the NIMBY (not-in-my-back-yard) attitude, believing that students learned library skills . . . in another class." ${ }^{12}$ However, more students say they were taught to use the library by a teacher or parent than by any other method.

\section{Conclusions}

Students today have had an entirely different library experience from the one their faculty had in school, and faculty need to realize this. Utilizing Liberspace can help students succeed and can influ-

\begin{tabular}{|lccc|}
\hline \multicolumn{4}{c|}{ TABLE 6 } \\
Learning to Use the Library \\
\hline & $\begin{array}{c}\text { How } \\
\text { professors } \\
\text { learned }\end{array}$ & $\begin{array}{c}\text { What professors } \\
\text { believe about } \\
\text { students }\end{array}$ & $\begin{array}{c}\text { How } \\
\text { students } \\
\text { learned }\end{array}$ \\
\hline On their own & $50.0 \%$ & $28.3 \%$ & $26.0 \%$ \\
Librarian consultation & 12.7 & 28.2 & 18.1 \\
Course/Part of a course & 16.2 & 25.0 & 22.0 \\
Teacher or parent & $\mathrm{n} / \mathrm{a}^{*}$ & $\mathrm{n} / \mathrm{a}^{*}$ & 28.7 \\
Other & 16.0 & 17.2 & $\mathrm{n} / \mathrm{a}^{*}$ \\
Don't know how & $\mathrm{n} / \mathrm{a}^{*}$ & $\mathrm{n} / \mathrm{a}^{*}$ & 4.7 \\
\hline Totals & $94.9 \%$ & $98.7 \%$ & $99.5 \%$ \\
*Question not asked of this group. & & \\
\hline
\end{tabular}


ence them to take maximum advantage of the library resources available. Our survey shows that after viewing this video, students will increase their fre-

\section{Our survey shows that after view- ing this video, students will increase their frequency of library use and their consultations with librarians during research.}

quency of library use and their consultations with librarians during research. This effect is especially strong among undergraduates but is even present among graduate students.
Although students in the present study indicated that their future behavior had been strongly influenced by viewing Liberspace, it would be useful to replicate the study with future students, employing both pre- and post-tests. This would enable the authors to test whether attitudes also shifted after such exposure. It is difficult to say, for instance, whether the impressive 87.8 percent who found librarians "helpful" held that attitude before viewing Liberspace or had a sudden epiphany during the viewing that here was a resource they had neglected. After all, 83.5 percent of those who found librarians helpful also said that libraries had no effect on them one way or another!

\section{Notes}

1. Elaine Woo and Nora Zamichow, "Cal State's Remedial Classes Help Chances, Students Say," Los Angeles Times, (Mar. 27, 1996), 1, 21.

2. Barbara Brandes, The Crisis in California School Libraries (Sacramento: California State Department of Education, Special Studies and Evaluation Reports Unit, 1987); Frank Johnson, Public Elementary and Secondary State Aggregate Data for School Year 1990-91 and Fiscal Year 1990 (Washington, D.C.: U. S. Department of Education, Office of Educational Research and Improvement, National Center for Education Statistics, 1992), 30; Laurel Daunis, "Temecula: Supporting School Libraries, against the Odds," Los Angeles Times, (Sept. 13, 1993), B4; Richard Lee Colvin, "School Libraries Shelved Amid Neglect," Los Angeles Times, (Apr. 21, 1996), A1.

3. Liz Gibson, The Impact of 1992/93 Budget Cuts on California Public Library Service: A Report of the California State Library (Sacramento: California State Library, 1993).

4. John Lolley, "Videotape Programs," Drexel Library Quarterly 16(Jan. 1980): 83-102; Gertrude Jacobson and Michael Albright, "Motivation via Videotape," Journal of Academic Librarianship 9 (Nov. 1983): 270-75; Robert C. Smith et al., "Making the Knowledge Connection: Video Based Library and Information Skills Instruction," International Journal of Instructional Media 20, no.1 (1993): 35-42.

5. Sherri Edwards, "Effects of a Self-Paced Workbook on Students' Skills and Attitudes," Research Strategies 9 (Sept. 1991): 180-88.

6. Liberspace is available for loan through LOEX and the California Clearinghouse on Library Instruction.

7. Lolley, "Video Programs," 83-102.

8. Gerard L. Hanley and Sharon L. Olson, "Preparing Incoming Students for the University Educational Process: From the Students' Perspective and Retrospective," Journal of the Freshman Year Experience 8 (May 1996): 47-77.

9. Constance Mellon, "Library Anxiety: A Grounded Theory and Its Development," College $\mathcal{E}$ Research Libraries 47 (Mar. 1986): 160-65.

10. Edwards, "Effects of a Self-Paced Workbook," 184-85.

11. Joy Thomas, "Faculty Attitudes and Habits Concerning Library Instruction: How Much Has Changed Since 1982?" Research Strategies 12 (fall 1994): 209-23.

12. Ibid., 216. 